\title{
Revolutionizing values in the Anthropocene with Arendt and Marcuse
}

\section{Revolucionando valores no Antropoceno com Arendt e Marcuse}

\section{Nuno Castanheira ${ }^{1}$}

\begin{abstract}
The concept of the Anthropocene finds its origins in geology and assumes that humanity has become a geological force, changing the Earth's environment in an unprecedented scale, blurring the dividing line between nature and society. This new understanding of the power of human beings is accompanied by the demand for a revolution in values capable of providing ways to deal with the situation we find ourselves in. The purpose of this paper is to briefly explore the use of the notion of Anthropocene as the focal point of an understanding of the radically new character of the current situation by way of its approximation to Hannah Arendt's notion of acting into nature, as well as to probe the critical analyses on value both of Arendt and Herbert Marcuse to provide a sketch of a possible way of dealing with the Anthropocene's demand for a revolution in values.
\end{abstract}

Keywords: acting into nature; understanding; ecological crisis; givenness; being-ofthe-world

\section{Resumo}

O conceito de Antropoceno tem a sua origem na geologia e assume que a humanidade se tornou uma força geológica, transformando o ambiente da Terra numa escala sem precedentes, tornado difusa a linha divisória entre natureza e sociedade. Esta nova compreensão do poder dos seres humanos é acompanhada

\footnotetext{
${ }^{1}$ Pesquisador PNPD/CAPES - PPG em Filosofia - PUCRS / Researcher PNPD/CAPES - Graduate Program in Philosophy - PUCRS. Membro-associado CFUL - Centro de Filosofia da Universidade de Lisboa / Associated-member CFUL - Center of Philosophy University of Lisbon.

E-mail: npcastanheira@gmail.com
} 


\section{2 | Dossiê - Natureza e Sociedade no Antropoceno - Superando a Separação?}

pela reivindicação de uma revolução nos valores capaz de fornecer formas de lidar com a situação em que nos encontramos. O propósito deste artigo é explorar, de modo breve, o uso da noção de Antropoceno como ponto focal de uma compreensão do caráter radicalmente novo da atual situação por via da sua aproximação à noção de ação na natureza de Hannah Arendt, bem como sondar as análises críticas do valor quer de Arendt, quer de Herbert Marcuse com vista a fornecer um esboço de um modo possível de lidar com a reivindicação de novos valores proveniente do Antropoceno.

Palavras-chave: ação na natureza; compreensão; crise ecológica; dação; ser-domundo.

\section{Anthropocene and acting into nature}

Human action over nature triggered a set of irreversible transformations in the Earth's ecosystems and their respective balances, transformations which seem now to be threatening the basic conditions of life as we know it. In The Human Condition, Hannah Arendt states that human beings have begun acting into nature, in the sense of having started to create natural processes that would have never come to existence without human intervention (ARENDT, 1959, p. 231). This human ability to start unprecedented natural processes whose outcome is unpredictable has shown both the fragile and the uncertain character of all there is, uncovering the fundamentally contingent givenness - phenomenologically speaking (ARENDT, 1959, p. 208) - of life itself².

The geological concept of the Anthropocene, put forward by Paul J. Crutzen and Eugene Stoermer, seems to open the possibility of scientific validation of Arendt's view by sustaining mankind's role as a powerful geological force, indirectly putting into question the Modern Age's conception of anthropos of which the latecapitalism of our day seems to be the ultimate expression, with its demands for everincreasing productivity, its concomitant exploitation of resources, and its

\footnotetext{
2 The concept of givenness (Gegebenheit) is the core principle of phenomenology (see HUSSERL, 2001). The principle was interpreted in several ways by the different philosophers of the phenomenological tradition and is one of the most challenging elements of any phenomenologically inspired perspective. The principle is indicative of the fact that every experience contains a dative element, it is always the giving of something to someone, in a specific way, a correlation whose terms are, in fact, inseparable, although analytically distinct. Broadly speaking, givenness is the core character of experience, which is to say of the phenomenon, the basic unit of phenomenology (see ARENDT, 1959; HEIDEGGER, 2001).
} 
transformation of even the limitations of the Earth's life support capabilities into mere barriers to be overcome by its limitless expansionist drive. More than trying to discuss the scientific elements and ramifications of the concept, this paper will be focused on exploring some of the critical and transfigurative potential of the notion regarding our understanding of the anthropos that is at its core, which is to say, of ourselves as beings-of-the-world. The paper will be based on Hannah Arendt's and Herbert Marcuse's contributions concerning a revolution in values apt to deal with the human being's contemporary condition, a condition that the concept of Anthropocene seems to encapsulate. At the center of this approach are Arendt's views on understanding, based on the influence of existential phenomenology in her writings (of which I will only present a very short account).

The escalation of the effects of human activity in the global environment in the last three centuries has significantly shifted its natural behavior, a shift that will extend through the next millennia and whose consequences are of such magnitude that they seem to have driven the Earth out of the Holocene, an age characterized by relative climate stability, suited to sustain life as we know it and where complex and technologically advanced human societies were able to develop (CRUTZEN, 2002). Otherwise put, human activities are threatening the Earth, the "quintessence of the human condition", the "[...] habitat in which [human beings] can move and breathe without effort and without artifice” (ARENDT, 1959, p. 2)

Although work in System-Earth science is still ongoing with the purpose of formalizing the Anthropocene as a geological age (WATERS et al., 2016; WILLIAMS et al., 2015), the fact is that the concept is already used as a critical and interpretive tool within the fields of natural science, social science and the humanities including philosophy and political theory (CLARK, 2015; PURDY, 2015; RAFFNSØE, 2016; STEVENS; TAIT; VARNEY, 2018) -, occupying an important place in decision-making, namely in international agreements regarding climate change goals (SCHELLNHUBER; RAHMSTORF; WINKELMANN, 2016; SCHLEUSSNER et al., 2016). This importance is justified insofar as recent studies show that human activities have triggered a set of feedback processes in the SystemEarth that are threatening to enter into a process of continuous warming of the planet, even if anthropogenic greenhouse gas emission levels are lowered (DONGES et al., 2017; STEFFEN et al., 2018). 


\section{4 | Dossiê - Natureza e Sociedade no Antropoceno - Superando a Separação?}

In accordance with the concept of Anthropocene, these studies share the call for an urgent reconsideration of human societies and activities as integral, interacting parts of the System-Earth, so that human beings consciously and responsibly acknowledge their role as geological forces, thus contributing for a redirecting of activities toward a stabilization of the planetary system as a whole (STEFFEN et al., 2018), preserving the "[...] basic conditions under which life on earth has been given to man" (ARENDT, 1959, p. 7).

Another element shared by the distinct disciplines and orientations in the Anthropocene debate is the emphasis on the ethical and political implications of this new era, namely regarding the values and norms shaping human behavior so far and their unsuitability in the context of a consideration of human beings as capable of "acting into nature" and the unpredictability of the effects of that action in the socioenvironmental network they inhabit.

The consequence is the call for an urgent transformation in values, some even calling for a second Copernican revolution (SCHELLNHUBER, 1999) in the way we conceive the planet - emphasizing the complex, dynamic and unique character of the planet's system - and how we conceive the relation between nature and society, not only regarding everyday life, but also regarding research - appealing to an rejection of the dualistic way of understanding constituting the ontological and epistemological basis of Modernity and the technoscientific view developed from it, dominant in our time (O'BRIEN et al., 2013). More than trying to discuss the scientific elements of the Anthropocene and their ramifications, this paper will focus on exploring its critical and transformational potential pertaining a renewed understanding of the anthropos at its core.

In this regard, some criticism were already directed to the concept of Anthropocene, pointing to the facto that it ignores economic, social and political inequality related to the exploitation and consumption of the Earth's natural resources, thus risking to reiterate the political homogenization, universalization and naturalization typical of the Modern colonial period, thus unfairly distributing the responsibility for the current situation, artificially abolishing the difference between those who took the most advantage from it and those that were and are their main victims ${ }^{3}$ (MALM; HORNBORG, 2014). This is a politically decisive

\footnotetext{
3 Broadly speaking, the first would be the countries from the Northern hemisphere, more precisely from the Western quadrant, and the second would be, with a few exceptions, the countries of the 
aspect in the distribution of responsibilities in the application of measures toward the transformation of the status quo. These criticisms are, therefore, very important and were accompanied by alternative proposals which included replacing the Anthropocene by Capitalocene (MOORE, 2016), as well as leading to the reformulation of the models for assessing the System-Earth in its relation with socioeconomic trends, which now include the aforementioned inequalities (STEFFEN et al., 2015).

Despite the relevance of these criticisms and the need to highlight, consider and correct the inequalities they point out, the fact is that the Anthropocene seems to encapsulate a condition that is common to every human being and human collective, a condition that regards their ability to "act into nature", in accordance with Arendt's formula, which is now bound to the ontological-political condition of our world. By using the expression. "ontological-political", my intention is only to show the bond at the center of the ecological crisis, the bond between the ethicalpolitical condition of the human being and its ontological condition, as well as the need to question it, a need that is the basis of every call for a transformation in values coming from the thinkers of the Anthropocene. Therefore, it is not an attempt to naturalize the current condition, but its opposite, i.e., to acknowledge, on the one hand, the human ability to trigger processes that endanger its own basic living condition, thus reaching an ontological dimension and, on the other hand, the human ability to act freely, in the sense of dealing with that critical condition regardless of the uncertainty and unpredictability associated with it and with action. In the words of Antonio Negri, the condition of crisis pertains the ontological constitution of the human being (NEGRI, 1999, p. 73), carrying out a movement from politics toward ontology that, according to Giorgio Agamben, brings politics back into its ontological position, that is, to the position of first philosophy (AGAMBEN, 1998, p. 44). Paraphrasing Negri, to accept that the human being is the locus of crisis is to accept a postfoundational view and the fact of the potential foundational character of human existence or, in Arendtian terms, is to accept the ontologically rooted fact of natality, the condition of possibility of political action and, therefore, of every possible foundation (ARENDT, 1959, p. 247; NEGRI, 1999).

global South. To address this criticism, Steffen, Broadgate, Deutsch, Gaffney and Ludwig (2015) divide their analysis into OECD countries and non-OECD countries. 


\section{6 | Dossiê - Natureza e Sociedade no Antropoceno - Superando a Separação?}

As a critical and interpretive methodological approach to facts, political ontology has a phenomenological-existential basis, consisting in the study of what is politically at stake in the ontological question (ABBOTT, 2014; HEIDEGGER, 2001; MARCHART, 2007; SAAR, 2012), providing analyses of the ways the ontic possibilities of human coexistence are conditioned by ontology, insofar as ontological presuppositions determine the epistemological and methodological approaches to ethics and politics. Political ontology uses a phenomenological methodology applied to understanding existence from the point of view of the basic experiences of being-with-others, bringing to light critical elements usually covered by naturalization and reification of political experience (MARDER, 2010, p. 4).

\section{Understanding and existential politics}

For Arendt, understanding is "[...] the specifically human way of being alive [...]" (ARENDT, 1994, p. 308), an unending activity through which we try to be at home in a world into which we are born - that is, into which we appear - and which we leave when we die - that is, from which we disappear. The world is the ultimate referential horizon of an existential situation with which each one finds itself irretrievably engaged by the mere fact of being alive. From the human being's point of view, the world constitutes a kind of factual a priori put into question simply by being alive. To understand the world is to understand one's own individual interval of time between being born and dying. Therefore, to understand the world is to examine the prejudices that are part of everyday life and are shared with others. Arendt calls "preliminary understanding" to the set of given criteria for judging and valuation that constitute the world at our arrival (ARENDT, 1994, p. 310). These shared values or criteria fulfill two main purposes: on the one hand, they serve as functions for the reproduction of a given, already existent socialized form of life; on the other hand, they preserve the potential for emancipation of individual life and of the world itself, transcending the economic order of value reproduction, thus opening the way to the realm of political experience. In fact, questioning the world is a fundamentally political issue, insofar as, in Arendt's, words, "Man cannot live without prejudices [...]. That is why in all times and places it is the task of politics to shed light upon and dispel prejudices [...]" (ARENDT, 2005, p. 99). 
Arendt's view on prejudices as social criteria of judgment seems to be broadly shared by Herbert Marcuse, for whom values are impersonal norms and aspirations that define and drive the needs of social groups and the process of their satisfaction. For Marcuse, it is true that this process is an expression of the demands of production and the patterns of consumption, but it also manifests the repressed possibilities that transcend the extant social system and its relations of production (MARCUSE, 2003, p. 195).

\section{Humanizing Nature, Naturalizing Society}

In her Prologue to The Human Condition, Hannah Arendt characterizes the Modern Age - the set of conditions presupposed by the modern world, that is, our own current factual situation - as guided by a systematic refusal of everything given and, ultimately, of givenness itself, widely understood as that which we have not ourselves created: life and the conditions of life on Earth. The purpose of this "rebellion against human existence as it has been given" from nowhere (ARENDT, 1959, p. 2) is, according to Arendt, to make all life artificial - that is, human made -, thus removing human beings from their dependence on nature once and for all. In The Lives of a Cell, Lewis Thomas states that the Modern Man's so called attempt to detach itself from nature by becoming its mastering force is one of the more consequential misconceptions of our time. This is an illusion, he says, because "Man is embedded in nature", this embeddedness being a fact of life for current biological science, and we will have to learn to "[...] cope with the dawning, intensifying realization of just how interlocked we are" (THOMAS, 2000, p. 358).

The unintended consequence of the process of mankind's supposed liberation from and refusal to acknowledge its embeddedness in nature and its limits - generally understood here as givenness and, therefore, a nature always already mediated by human activity -, might as well be mankind's liberation from itself and ultimately its dependence on constant dehumanizing in order to produce its own so-called exceptional human character. The systematic refusal of givenness has the perplexing consequence that the more human beings try to enforce their mastery over nature to assert their character as exceptions in the order of things, the more their own character as human beings becomes indistinct and the more "animalized" they become (see the anthropological machine AGAMBEN, 2012). In 


\section{8 | Dossiê - Natureza e Sociedade no Antropoceno - Superando a Separação?}

Arendtian terms, the homo faber, the protagonist of the Modern Age's brand of Anthropocentrism, quickly turns into the animal laborans and this means that the humanization of nature through dominion is accompanied by a naturalization of society and politics, producing an indistinctness that not only is at the core of the notion of the Anthropocene and the ecological crisis it encapsulates, but is also in line with Darwinian views of evolution, as argued by thinkers as Manuel AriasMaldonado (ARIAS-MALDONADO, 2015) and Joel Kovel (KOVEL, 2007), among many others.

According to Maldonado, socio-natural involvement is the central trait of our era and nature has been transformed into human environment, assigning human beings the responsibility over nature, and turning nature into an ethical and political entity (ARIAS-MALDONADO, 2015, p. 4-6). Against traditional views on nature that describe it as a static entity that exists independently of human intentions and purposes, Maldonado argues in favor of a Darwinian view according to which nature is an evolutionary process governed by universal laws, but also subjected to randomness and contingency, to which the intervention of different species adapting to their environment - including the human species - are relevant contributors (ARIAS-MALDONADO, 2015, p. 25).

In line with this, Kovel says that arguing that mankind is outside nature is absurd since all statements about nature are social statements, carrying human values into a natural world that is reconfigured by human influence (KOVEL, 2007, p. 95). For Kovel, "nature palpably exists irrespective of what we sat about it. And yet nature only exists for us insofar as we say anything about it" (KOVEL, 2007, p. 95); in other words, it could be said that its existence is dependent on a dative element, and to ascertain whether it exists or not beyond its givenness may well show to be a moot pursuit. Life - particularly, human life - is not created ex nihilo by humans, it is an event that finds its ultimate origin in nature phenomenologically understood as that which appears by itself and from itself, that is, not that which is merely given, but givenness itself (broadly speaking).

Humans are producers of change in nature; but humans are also products of nature and its transformation, conditioning but also being conditioned by everything given, both natural and artificial. Influenced by Marx's critique of capitalism, Arendt calls "metabolism of man with nature" to this entanglement between human beings and all that is given, entanglement which is viewed as the 
substratum of the life process of the species. This metabolism with nature is at the core of the laboring process and its interconnected stages of production, consumption and reproduction as understood by Arendt (ARENDT, 1959, p. 131).

If human embeddedness in nature is the case and nature is always already found within the human world and the human world always already conditioned by some kind of nature, then the central issue of the Anthropocene is to inquire how the human being must understand the world, itself and nature as givenness in order to deal with that currently blurred line between nature and society. And this must become the central issue of our time because the ecological crisis which we are experiencing is both an indictment of our current form of life - that is, of the way we understand the world, ourselves and, therefore, also nature - and an urgent call to free the potentialities of a conception of anthropos more in line with the human being's current ability to effect unprecedented change on the Earth's life systems. In other words, it calls for a new form of life grounded on a revolutionizing of values able to break the process of the more or less automatic, continuous exploitation of nature and human beings triggered by human acting into nature.

\section{The critique of value and the tragedy of the Modern Age's view of Anthropos}

Indistinctness between nature and society is, therefore, the hallmark of our time and one of the underlying driving issues of the concept of the Anthropocene. For Arendt, indistinctness is a sure sign of crisis, the experience of an interruption of a willed continuity in time that blurs everything that once seemed self-evident and was taken for granted. A crisis takes place when the values, norms or criteria formerly used to guide us through everyday predicaments are no longer reliable (ARENDT, 2006, p. 171). However, this does not necessarily mean that the unreliability of past criteria to judge new conditions entails an interruption in their use. If left to their own devices, these values or criteria will simply continue to produce and reproduce the indistinctness - that is, the crisis - at their basis, thus widening its scope and its consequences without dealing with it (ARENDT, 2006, p. 171). And that is particularly risky in times of an ecological crisis that has reached ontological levels. 
As I mentioned above, the process of humanizing nature - of disposing of nature as a material means for human ends - has been accompanied by the naturalizing of society - by the transformation of human beings themselves into material means for continuously sustaining, producing, and reproducing the modern socialized form of life. In accordance with Arendt, this occurs due to a blurring of the distinction between means and ends, a blurring that she calls "the tragedy of homo faber", that is, the tragedy of Anthropocentrism (ARENDT, 1959, p. 155).

In The Human Condition, Arendt argues that machines have introduced a significant difference in the production process and the human being's relation with the implements of production. While the use of tools in manufacturing allowed for a clear distinction between the producer and the tools freely used as means to produce a particular end product - meaning that although human beings produced representations of themselves, these did not actually change their nature of producers -, machines take advantage of the laboring motion of the body and its rhythm to unify individual movements, turning the coordinated motion of the machine itself into the subject of production, instead of the individual, and production into a never ending, autonomous process in which the distinction between means and ends is no longer meaningful. This is a process of naturalization, a hybrid between the self-appearing process that characterizes the existence of natural things and the human fabrication process, where the existence of the produced thing is distinct from the process of its fabrication (ARENDT, 1959, p. 150-154). Citing Werner Heisenberg, Arendt says:

\footnotetext{
[...] the world of machines has become a substitute for the real world [...]. The natural processes on which it feeds increasingly relate it to the biological process itself so that the apparatuses we once handled freely begin to look as though they were "shells belonging to the human body as the shell belongs to the body of a turtle". [...] Technology in fact no longer appears "as the product of a conscious human effort to enlarge material power, but rather a biological development of mankind in which the innate structures of the human organism are transplanted in an ever-increasing measure into the environment of men". (ARENDT, 1959, p. 152-153)
}

And herein lies the tragic aspect of Anthropocentrism, the Modern Age's understanding of the anthropos. In Arendt's view, all value is a relation between one possessed thing and another, that is, exchange value dependent on socioeconomic needs and rules of supply and demand. This means that everything 
may be turned into a commodity or into a potential commodity, thus losing what Arendt, using a Lockean expression, calls its "natural intrinsic worth", i.e., a worth or dignity of its own; in ontological language, it could be said it loses its ownmost being, as it is given. Therefore, says Arendt, the modern world - that is, the world built upon the prejudices or values of the Modern Age - is characterized both by the loss of intrinsic worth - nothing has value independently of the estimations of supply and demand - and universal relativity - a thing exists only in relation to other things, including human beings themselves, whose worth as producers is alienated into a commodity - self-alienation - and as laborers into a function of the laboring, biological process of society - naturalization with subsequent worldalienation and loss of "natural intrinsic worth". A good example of this process of degradation of the worth of everything into exchange values while integrating them into an economy of production and reproduction is the current policy effort to turn the discussion on nature and so-called natural values into a discussion of ecosystem services, prefiguring the inevitable translation of those services into money - the only common denominator that transcends all use value - and the ensuing attribution of a price to things like water, air, photosynthesis and so on 4 .

The tragedy of Anthropocentrism lies in the fact that human beings built a world of ends in conformity with their purposes and for their use just to realize that every end is just a means in a never-ending chain, entailing that mankind, as it is given to itself and understands itself in the world it built for itself, also becomes a means to something else, alienating its own world and thus losing its intrinsic worth, its dignity, a meaning that is properly its own. It is precisely when all there is becomes subsumed to human purposes, realizing the Modern Age's refusal of givenness, that the utilitarian world becomes meaningless to those who built it. Paraphrasing Marcuse's critique to vulgar Marxist materialism (MARCUSE, 1978, p. 1-4) - whose perspective, in this regard, is very close to Arendt's views on the animal laborans (ARENDT, 1959, p. 321) -, the reification of nature by human beings lead to the reification of their own subjective, individual lives, turning them into mere functions of reproduction of the automatic processes of a collective whole, that is, of a preexisting social-economic order. Although modern society seems to

\footnotetext{
4 Which does not mean actual monetization of nature but represents another step in the process of capitalization of everything, i.e., of turning everything into actual or potential value for investing or exchange in order to become surplus value and, eventually, to turn a profit.
} 
be more humane, its highest value is, in fact, the smooth functioning of the anthropological machine that turns everything into a commodity or potential commodity, including the creative, productive power of human beings, either in actuality or as a potentiality to be traded or invested in the exchange market.

This situation is irreversible and constitutes the material condition of the modern world's existence. However, this does not mean that it is unchangeable. In fact, this is, using Arendt's words, "[...] a political question of the first order [...]" (ARENDT, 1959, p. 3). It marks, on the one hand, the failure of the modern project to refuse everything given and, most importantly, givenness itself, in the name of human freedom, leading to the alienation of the latter. Human beings are characterized by the fact of their existence being conditioned even by human-made things. In Marcuse's words, there can be no "total abolition of alienation" (MARCUSE, 2003, p. 198). Otherness is constitutive of everything there is, and every single human being struggles with some kind of "nature". Total success in mastering nature would paradoxically result in the abolition of the human being's own distinctive way of being. Therefore, critical efforts should be directed to the abolition of what Marcuse calls "surplus alienation, namely the alienation exacted by the existing society in the interest of maintaining and enlarging the status quo" (MARCUSE, 2003, p. 197-198); in other words, the alienation produced by the selfpreserving, autonomous processes of the existing socioeconomic order, whose selfreproducing crisis is on the basis of current dehumanization, repression, environmental exploitation and destruction. According to Marcuse:

This surplus alienation has been the soil on which quantitative progress
has taken place: it has sustained the separation of intellectual from manual
labor, the need and the growing need for dehumanizing, parasitarian and
destructive work, the need for repression; it has wasted and polluted the
available resources - technical, natural and human. Quantitative progress
now could, and should, turn into quality: a new mode of life which would
free the potentialities of man and nature by negating the established
system of exploitation and its values. This transformation of values would
not only invalidate the existing political and economic institutions, it
would also make for a new morality, for new relations between the sexes
and generations, for a new relation between man and nature. (MARCUSE,
2003, p. 198)

On the other hand, it shows that the failure of Anthropocentrism is not necessarily the same as the failure of the anthropos which is at the core of the concept of the Anthropocene. On the contrary, it seems to point to the fact that only 
a critical reconsideration of the Anthropos and the reimagining of the dividing line between nature and society - in contrast with its simple renunciation in the name of biocentric or similar views or yet its blind reaffirmation even in the most emancipatory of modern terms - will enable us to find a way out of the current crisis.

The question is: how?

\section{Towards a revolution values in the Anthropocene: a brief sketch}

Unfortunately, I will not be able to explore this in depth, but I will try to briefly present one or two elements of this change in point of view with potential material consequences for our way of life.

Both Arendt and Marcuse assign a central role in this revolution in values to art. Marcuse adopts the Marxian theory of value transformation, arguing that every new set of values is an articulation of the interests of a particular class trying to pass as universal interests, assuming an ideological character. For Marcuse, values are ideological insofar as they abstract from their limitations in reality. However, the process of change begins precisely when ideology becomes a material political force in the process of realization of the abstract values, thus making their inner limitations manifest (MARCUSE, 2003, p. 196). This means that, although they are not directly derived from preexisting values as their mere unrealized possibilities, new values precede institutional changes in production and social relations, they are a result of the creative, subversive potential of life itself. According to Marcuse, the transformation of values is not a mere ideological reflection of the social structure, but an articulation of new possibilities yet to be incorporated into the process of social change whose catalyst is intellectual, instead of social, revolution (MARCUSE, 2003, p. 196-197). What does this mean?

For Marcuse, radical change must be rooted in the subjectivity of individuals, in their own individual passions, desires, drives and goals, instead of being subjected to the process of production of needs and their satisfaction imposed upon them by the existing social structure through a reified collective consciousness. In other words, there must occur a revolution in aesthetics and, therefore, in perception that enables individuals not only to be aware of the given material conditions of their lives, but also to be able to distinguish between those conditions 
which are due to the fact that humans are conditioned beings and those that are imposed upon them in the name of exploitation by the set of dominant values, the status quo. Since the modern world is characterized by universal relativity and loss of intrinsic worth, this means that there must be some kind of object that is able to be removed from the context of use and from the exchange market and represent the world as it is, in its conditioned and conditioning character. This will enable individual, subjective consciousnesses to be removed from the network of exchange relations and to enter into another dimension of existence, that of the non-material activity of thinking that can revive the intrinsic worth of things and become a material, revolutionary force.

That object is the work of art. Works of art are also the products of reification and materialization and therefore are, in Arendt's words, a kind of "dead letter" where the "living spirit" - that is, the free, creative, productive force of individual life in itself and for itself, delivered from the constraints of social criteria in thinking - is allowed to appear in its own figure and beyond its functional use (ARENDT, 1959, p. 95). But they can anticipate social change since they open a horizon of change. Thinking is, for Arendt, the examination of the fact of being alive - which means, in the modern world, simultaneously being a part of a society of laborers and individual interval of time between being born and dying - focusing not on its products or reproductive function within a socioeconomic order governed by a set of given values and criteria - but on the activity itself that is their ground, on the subjective, individual, distinctive character of the needs that drive it, particularly the need of the individual to find a meaning of his or her own and the dispelling of the prejudices in the way of that meaning (ARENDT, 1978, 2005). That is why Marcuse says that a work of art is revolutionary if it represents, in the exemplary fate of individuals, the prevailing non-freedom and the rebel forces that break through a mystified and petrified reality, "opening the horizon of change (liberation)" (MARCUSE, 1978, p. xi).

Therefore, if the criteria through which something must be judged is its adequacy or inadequacy to the form or eidos that allows it to appear as it is, then it must be said that such a form or eidos - the criteria or norm for judging all things - is neither the exceptional character of the human being nor its naturalization as it occurs in our current social conditions. It is rather the groundless, an-archic, fundamentally free character of the world's givenness - nature included - which is 
represented and actualized in revolutionary works of art as alienated, thus unleashing all their subversive and revolutionary potential. And this results in a stance toward otherness - including one's own - and its respective possible worlds that potentially the way for the anthropos of the Anthropocene to be a revolutionary of values, an example of responsibility toward and openness to the givenness of all there is, that is to say, to everything that appears in itself and for itself, instead of an exception in the order of everything that is, trying to dominate it in the name of usefulness and ending up by becoming a useful, meaningless function of socioeconomic life in the process.

\section{References}

ABBOTT, Matthew. The Figure of this World: Agamben and the Question of Political Ontology. Edinburgh: Edinburgh University Press, 2014.

AGAMBEN, Giorgio. Homo Sacer: Sovereign Power and Bare Life. Stanford: Stanford University Press, 1998.

AGAMBEN, Giorgio. The Open: Man and Animal. Stanford: Stanford University Press, 2012.

ARENDT, Hannah. The Human Condition. Chicago: University of Chicago Press, 1959.

ARENDT, Hannah. Thinking. In: MCCARTHY, Mary (org.). The Life of the Mind. One Volume ed. New York: Harcourt, Inc., 1978.

ARENDT, Hannah. Understanding and Politics (The Difficulties of Understanding). In: KOHN, Jerome (org.). Essays in Understading: 1930-1954 - Formation, Exile, and Totalitarianism. New Edition. New York. p. 307-27.

ARENDT, Hannah. Introduction "into" Politics. In: The Promise of Politics. New York: Schocken Books, 2005. p. 93-200.

ARENDT, Hannah. The Crisis in Education. In: Between Past and Future: Eight Exercises in Political Thought. New York: Penguin Books, 2006. p. 170193.

ARIAS-MALDONADO, Manuel. Environment and Society: Socionatural Relations in the Anthropocene. SpringerBr ed. Cham: Springer International Publishing, 2015.

CLARK, Timothy. Ecocriticism on the Edge:The Anthropocene as a Threshold Concept. London; New Delhi; Sidney; New York: Bloomsbury Academic, 2015 . 
CRUTZEN, Paul J. Geology of Mankind. Nature, v. 415, n. 6867, p. 23-23, 2002. DOI: $10.1038 / 415023 a$.

DONGES, Jonathan F.; WINKELMANN, Ricarda; LUCHT, Wolfgang; CORNELL, Sarah E.; DYKE, James G.; ROCKSTRÖM, Johan; HEITZIG, Jobst; SCHELLNHUBER, Hans Joachim. Closing the loop: Reconnecting human dynamics to Earth System science. The Anthropocene Review, v. 4, n. 2, p. 151157, 2017. DOI: 10.1177/2053019617725537.

HEIDEGGER, Martin. Being and Time. Oxford: Blackwell Publishers Ltd., 2001.

HUSSERL, Edmund. Logical Investigations - Volume I. London: Routledge, 2001.

KOVEL, Joel. The Enemy of Nature - The End of Capitalism or the End of the World? London; New York; Halifax; Winnipeg: Zed Books; Fernwood Publishing, 2007.

MALM, Andreas; HORNBORG, Alf. The geology of mankind? A critique of the Anthropocene narrative. Anthropocene Review, v. 1, n. 1, p. 62-69, 2014. DOI: 10.1177/2053019613516291.

MARCHART, Oliver. Post-foundational Political Thought Political Difference in Nancy, Lefort, Badiou and Laclau. Ipswich: Ebsco Publishing, 2007.

MARCUSE, Herbert. The Aesthetic Dimension - Toward a Critique of Marxist Aesthetics. Boston: Beacon Press, 1978.

MARCUSE, Herbert. A Revolution in Values. In: DOUGLAS KELLNER (org.). Towards a Critical Theory of Society. London and New York: Routledge, 2003. p. 195-201.

MARDER, Michael. Groundless Existence: The Political Ontology of Carl Schmitt. New York; London: Continuum, 2010. DOI: 10.1080/09672559.2011.547097.

MOORE, Jason W. (ORG.). Anthropocene or Capitalocene? Nature, History, and the Crisis of Capitalism. Oakland: PM Press, 2016.

NEGRI, Antonio. Insurgencies: constituent power and the modern state. Minneapolis: University of Minnesota Press, 1999.

O'BRIEN, Karen et al. You say you want a revolution? Transforming education and capacity building in response to global change. Environmental Science and Policy, v. 28, p. 48-59, 2013. DOI: 10.1016/j.envsci.2012.11.011.

PURDY, Jedediah. After Nature: A Politics for the Anthropocene. Cambridge, Massachusetts; London: Harvard University Press, 2015.

RAFFnSØE, Sverre. Philosophy of the Anthropocene: The Human Turn. 
London: Palgrave Macmillan UK, 2016. DOI: 10.1057/9781137526700.

SAAR, Martin. What is Political Ontology? Review of: Oliver Marchart (2010) Die politische Differenz. Zum Denken des Politischen bei Nancy, Lefort, Badiou, Laclau und Agamben. Krisis - Journal for Contemporary Philosophy, n. 1, p. 7983, 2012.

SCHELLNHUBER, H. J. Earth system analysis and the second Copernican revolution. Nature, v. 402, p. C19-C22, 1999. DOI: 10.1038/35011515.

SCHELLNHUBER, Hans Joachim; RAHMSTORF, Stefan; WINKELMANN, Ricarda. Why the right climate target was agreed in Paris. Nature Climate Change, v. 6, n. 7, p. 649-653, 2016. DOI: 10.1038/nclimate3013.

SCHLEUSSNER, Carl-Friedrich et al. Science and policy characteristics of the Paris Agreement temperature goal. Nature Climate Change, v. 6, n. 9, p. 827-835, 2016. DOI: $10.1038 /$ nclimate3096.

STEFFEN, Will et al. Trajectories of the Earth System in the Anthropocene. Proceedings of the National Academy of Sciences, v. 115, n. 33, p. 82528259, 2018. DOI: 10.1073/pnas.1810141115.

STEFFEN, Will; BROADGATE, Wendy; DEUTSCH, Lisa; GAFFNEY, Owen; LUDWIG, Cornelia. The trajectory of the Anthropocene: The Great Acceleration. The Anthropocene Review, v. 2, n. 1, p. 81-98, 2015. DOI: $10.1177 / 2053019614564785$.

STEVENS, Lara; TAIT, Peta; VARNEY, Denise (ORG.). Feminist Ecologies Changing Environments in the Anthropocene. Cham: Palgrave Macmillan, 2018.

THOMAS, Lewis. The Lives of a Cell. In: OATES, Joyce Carol; ATWAN, Robert (org.). The Best American Essays of the Century. New York : Houghton Mifflin Company, 2000. p. 358-360.

WATERS, C. N. et al. The Anthropocene is functionally and stratigraphically distinct from the Holocene. Science, [S. l.], v. 351, n. 6269, p. aad2622-aad2622, 2016. DOI: $10.1126 /$ science.aad2622.

WILLIAMS, Mark; ZALASIEWICZ, Jan; HAFF, PK; SCHWÄGERL, Christian; BARNOSKY, Anthony D.; ELLIS, Erle C. The Anthropocene biosphere. The Anthropocene Review, v. 2, n. 3, p. 196-219, 2015. DOI: 10.1177/2053019615591020.

Recebido em: 19/11/2020. Aprovado em: 21/12/2020. Publicado em: 26/12/2020. 